\title{
THE ROLE OF RECOMMENDATIONS IN PROMOTING SERVICES OF POLISH UNIVERSITIES
}

\author{
EWA PRYMON-RYŚ
}

AGH University of Science and Technology, Faculty of Management, Cracow, POLAND

e-mail: eprymon@zarz.agh.edu.pl

\begin{abstract}
\begin{tabular}{l|l} 
RECEIVED & 5July 2017
\end{tabular}
ACCEPTED $\quad 15$ December 2017

JEL

CLASSIFICATION

D91, I23, L86, M31

KEYWORDS recommendations, buzz marketing, higher education, surveys, Poland

ABSTRACT Recommendations and "word-of-mouth" play an important role in service marketing. This specific form of communication involves supporting a product or service by a satisfied customer. "Word of mouth" is very helpful in building awareness of a brand, also in the higher education market. This paper provides some insight into a decision-making process of young people, who make the decision concerning the next step of their education, thus enabling the universities to develop the efficient communication program. Considering influence of recommendations on potential students, universities must learn how to use social ties to promote the educational offer.

The outcomes of survey conducted among Polish students will be also discussed, to evaluate, to what extend recommendations and word-of-mouth determined their choice of the particular university. Main goal of the paper is to discuss the usefulness of recommendations in the communication-mix of the universities. In that sense, it provides the contribution to service marketing practice.
\end{abstract}

\section{Introduction}

In common sense, the main factor influencing the choice of higher education is the quality of the services offered by an educational institution. According to Pabian (2005) the quality of educational services is defined as the level of satisfaction of needs and requirements of students, resulting from the educational and non-educational activities of the university. This quality is determined by university staff, physical environment of the university, 
teaching processes and other factors, not related to the educational offer itself. Quality of university services may be measured and managed (Hall, 2007). However, it is difficult to assess, to what extent it influences the prospect students' choice of a faculty or a university course. It may be assumed, that potential students try to make rational and logical decisions regarding the perfect choice of their future by collecting, absorbing and storing data concerning the selected university. Despite the high level of involvement of candidates and their family in the decision-making process (Moogan, Baron, 2003) and many factors affecting potential students' "buying behavior" identified (Hobsons, 2013; Vrontis, Thrassou, Melanthiou, 2007), there is still a lot to learn about the real determinants of the ultimate selection. One of the important factors is the role of other people's influence over their decision.

Practical implications of such findings should help in planning the communication program of the university.

\section{Literature review}

Students enroll in university for various reasons. For example: to develop their future career, to improve their social status, to become independent from the parents, to delay their "grown-up life" and work. According to Hall (2007) potential students can be divided into several groups: quality-of-education-oriented, career-oriented, searchers-for-knowledge, scientific-title-oriented, comfort-oriented (those who search for simple enrollment procedures). For each of these specific segments, different selection criteria may play an important role.

Nowaczyk and Kolasinski (2007) indicated several elements determining the competitiveness of Polish universities, such as: scientific staff, number of students, teaching programs, tradition, position in university rankings, relations with foreign scientific and research centers etc. Some of them certainly may be treated as hints for candidates. Taking into account a personal situation of a student, sometimes social-support programs or easy and quick access to university premises may decide. However, not only the objective, measurable factors matter. The candidates' decision-making process is influenced by perceived attractiveness of university atmosphere, social network influences and individual motivations. One should not ignore the expected benefits, imaginations of "student-life" and sometimes unrealistic expectations regarding the post-graduate career. Such expectations may appear on a basis of stories told by colleagues, family members' recollections or other informal sources of information such as Facebook or YouTube. Recently, many research articles regarding the impact, that such social media have on the decision making process of future students, were published (Constatinides, Zinck Stagno, 2012; Hobson, 2013; Sankaran, Kannan, 2016). Many universities have adopted social media to recruit students and to communicate with graduates and current students. However, the effectiveness of social media in the context of attracting potential students and promoting educational services in the Polish higher education sector has not been sufficiently evaluated. Obviously, Polish teenagers and high school graduates use Facebook and other social media tools; therefore the information gathered through these communication channels may support the university choice. However, official fan-pages of faculties and universities are perceived by youth as dull and, somehow, "less reliable" than funny memos or messages shared by a friend. The role of social media in the phase of information search (Pabian, 2005) should not be overestimated. According to results of international students' research (Hobsons, 2013) direct email or phone conversation with a college officer was more than twice as important as social media.

On the contrary, opinions from people, who are current or former students of the university, are the most reliable sources of information and also important decision variables. In the research cited (Hobsons, 2013) more than $50 \%$ respondents indicated recommendations from university alumni as the criterion of their choice; recommendations from friends/family were mentioned by $38 \%$ of the students. 
In addition, friends as the source of information were on the 4th position in the ranking, just after university webpage, electronic prospects and email communication with the recruitment office. According to Sweeney, Soutar and Mazzarol (2008), word-of-mouth recommendations and referrals are strong factors that can influence students' decision-making processes.

Since friends, trusted advisors, relatives, and family members may strongly affect the decision-making process of young people, the outcomes of the conducted research should give the answer to what extend recommendations and word-of-mouth determined their choice of the particular Polish university. On the basis of these results it will be worth considering, how the recommendations and referrals may be managed for the promotional purposes. Certainly the relationship marketing approach should be also implemented here.

\section{Research method}

The research was conducted to investigate the usefulness of buzz-marketing tools for promotion and recruitment processes in Polish universities and to study the impact of recommendations on the choice of educational institutions by potential students.

The survey was focused on Polish students from several Polish public universities located in Cracow, Katowice, Poznan, Rzeszow, Szczecin, Warsaw, Wroclaw and other cities.

The main goal of the referred survey was to identify the factors influencing the choice of the university by candidates. One of the specific objectives of the study was to evaluate the influence of recommendations on decision-making of prospect students.

The research objectives were aligned with the several secondary questions, among others:

- to determine, if potential students make use of recommendations for university selection,

- to determine, if recommendations influence the university selection process of potential students.

Research was conducted to collect data from young people currently studying in different public Polish universities. Primary data was collected in May-June from 242 respondents. The research method was CAWI (Computer-Aided Web Interview). A convenient sampling approach ('snow ball') was used to select respondents for this study; an invitation for the survey and a link to the online questionnaire was delivered to Polish students by emails and Facebook messages.

The literature review was used as the source of information to create the questionnaire, while a combination of closed- and open-ended questions was used.

\section{Results}

242 current students participated in the survey: 160 women and 82 men, aged 20 to 33 . In majority the respondents were full-time students $(81.8 \%)$. Only 30 respondents (12.4\%) were studying at more than one faculty at the same time. In case a respondent was a student of more than one educational institution, one was asked to answer the questions with the regard to the university considered as foreground.

The respondents were asked to indicate, how many years they had studied at their current faculty. Figure 1 shows the 'year-of-study' structure of the sample. One-third of the group was $1^{\text {st }}$ year students. 


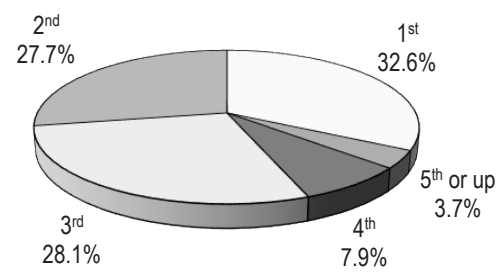

Figure 1. Structure of the sample concerning the current year of study at the university

Source: own study based on surveys.

In the sample dominated students from Cracow (33.9\%), Katowice (18.6\%), Rzeszow (11.6\%) and Warsaw $(9.5 \%)$. It must be noted that the study was limited to public universities only, but not restricted to specific university type.

To evaluate the impact of the immediate student's environment on the university choice, respondents were asked to recall how many classmates from their final class in high school had chosen the same college (see Figure 2). For almost $80 \%$ of the sample the decision regarding the selected university was taken jointly with other classmates. $15.7 \%$ students choose the same university as one of his/her acquaintances, $48.3 \%$ of the students made the same decision as $2-5$ other classmates. These results show a very strong influence of teenagers' reference group over the decisions of potential students.

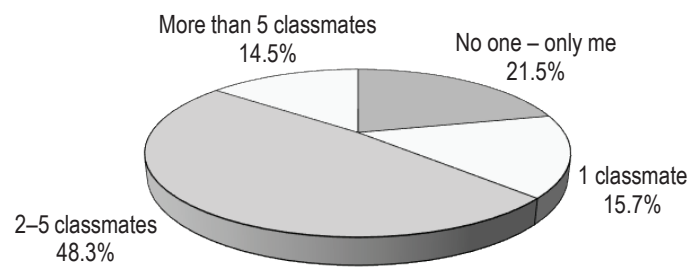

Figure 2. Number of classmates choosing the same university as the respondent

Source: own study based on surveys.

In addition the respondents were asked, how many close friends enrolled in the same faculty at the same university. Judging on the results (see Figure 3), the imitation effect plays an important role in decision-making of prospect students (Moogan, Baron, 2003).

More than half of the surveyed group of students $(52.1 \%)$ has chosen the same faculty as (at least) one of his/her friends. Certainly the impact of friends' recommendations is an important factor in university selection process. 


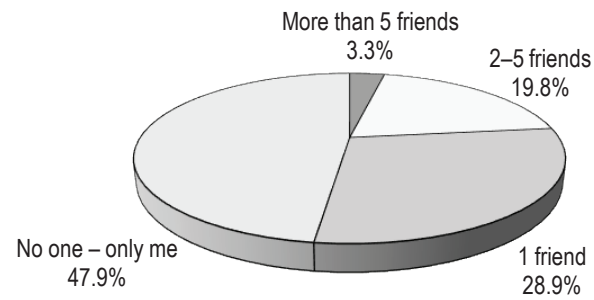

Figure 3. Number of respondent's friends attempting to enroll in the same faculty at the same university

Source: own study based on surveys.

These findings have been confirmed by outcomes of the next survey question, regarding sources of information used by potential students. Several answer options were drawn from the literature review (Moogan, Baron, 2003; Pabian, 2005; Hall, 2007) and included: educational fairs, university open days, online forums, social media, university rankings, promotional materials, university website, recommendations, etc. Figure 4 shows the predominance of direct sources of information accompanying by the official university webpage.

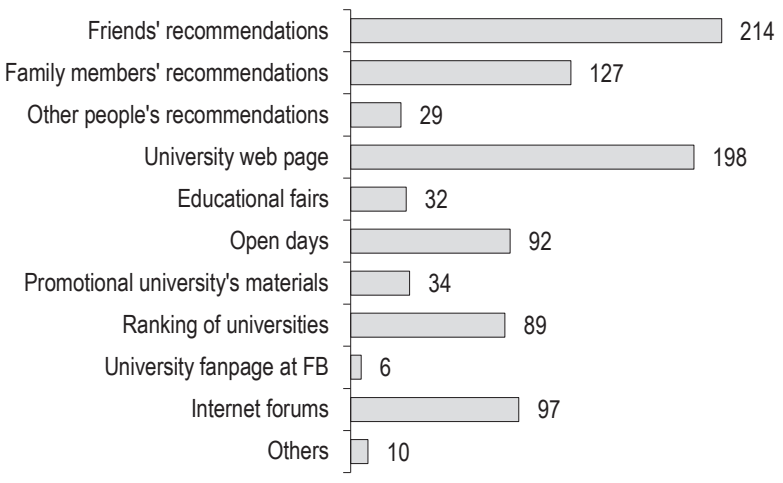

Figure 4. Sources of information used by respondents

Source: own study based on surveys.

Almost all candidates $(88.4 \%)$ consulted their choice with friends, family members $(52.5 \%)$ or strangers (12\%). This means, that potential students treat the recommendations as the most reliable and hence, the best source of information. The vast majority (81.8\%) sought information on the official website of the university. Surprisingly, the official Facebook fanpages reached rather low position in the ranking (only $2.5 \%$ indications), despite the fact, that teenagers are the most frequent social media users and according to other studies (Constatinides, Zinck Stagno, 2012; Sankaran, Kannan, 2016; Smedescu, Ivanov, loanas, Fruth, 2016) social media may be successfully used for promotion and recruitment purposes. It may be assumed, that the content of official university fanpages does not attract young people's attention. 
Open days have been mentioned by several respondents (38\%) along with the educational fairs $(13.2 \%)$, because such events make possible the direct contact with the university and its representatives. Open days also enable interactions with current students, who are perceived as truthful and well-informed, when asked about the campus atmosphere and studying conditions.

It must be noted, that the universities' overall quality, as described by Pabian (2005) and Hall (2007) is reflected in rankings of universities and colleges, published annually by few Polish magazines. For candidates (and undoubtedly their parents) the university's position in such rankings is an important influencing factor (36.8\% indications). Figure 5 gives insight into the main determinants of prospect students' decision-making.

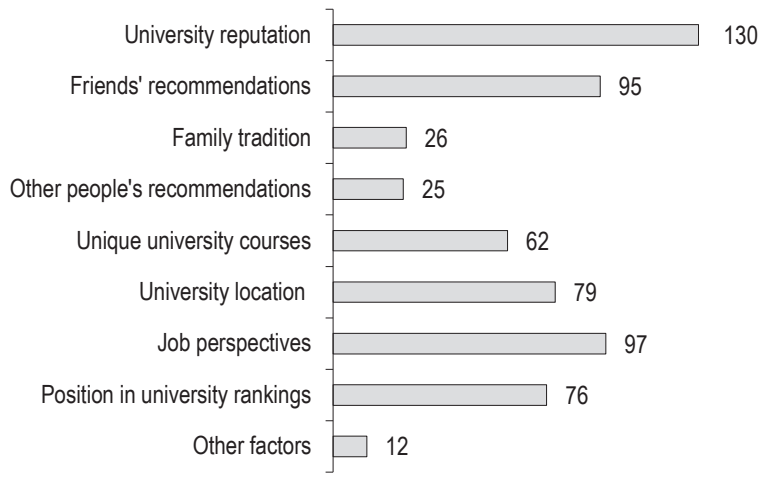

Figure 5. Determinants of the university choice perceived by respondents

Source: own study based on surveys.

More than $50 \%$ of the sample (130 respondents) paid attention to the reputation of the university. This means that students choose an institution, on which there is widespread belief that it is good and represents a high level of education. The reputation reflects also on the position of a university in published rankings. Perspectives of a wellpaid job after graduation and friends' recommendations were consecutive determinants of candidates' choices.

In the conducted survey, respondents were also asked about the overall satisfaction on the studying in the current faculty. $57.9 \%$ of current students were satisfied with the choice they had made; $33.7 \%$ respondents were not sure, whether they are satisfied or not; as many as $8.7 \%$ of students have been studying, despite the fact that they regretted their choice and were not satisfied with the faculty and its offer. It is obvious, that if someone is dissatisfied with the chosen university, one will not encourage others. His/her prospect recommendation will be doubtful or misleading. It is evident, how important is implementation of relationship marketing approach in management of higher education services.

\section{Limitations}

Sampling method of this survey may affect the representativeness of data collected. Sampling frame of subsequent research should involve also part-time students and students from colleges and non-public educational institutions. 


\section{Conclusions}

Conducted research shows a considerable impact of recommendations on decisions of prospect students in Poland, regarding their choice of a university. The results of the current study are convergent with outcomes of other research studies (Moogan, Baron, 2003; Vrontis et al., 2007; Constatinides, Zinck Stagno, 2012; Hobsons, 2013).

Respondents have great confidence in opinions expressed by family members and friends. Young people imitate behavior of their classmates or close friends, and attempt to enroll together at the same university or faculty.

Furthermore, it occurs that the candidate's decision is influenced by unknown people, who are considered as experts i.e. other students or alumni. Candidates search for information about selected studies using online forums, absorbing opinions supplied by complete strangers.

In the view of the conducted study, it can be stated, that Polish universities should appreciate the importance of creating strong relationships with current students and alumni. Relational approach in managing higher education services (in the context of maintaining relationships with professors, students, scientific and administrative staff) may bear fruits of positive opinions about the organization and encouraging recommendations towards candidates. Post-graduated students' associations and alumni reunion meetings may help in preserving university traditions and promoting its good reputation. Thus, promotion of university services may be significantly supported by good recommendations from satisfied students, postgraduates and the university staff.

Considering immense influence of recommendations on decision-making of potential students, universities must learn how to use social ties of young people, to promote the educational offer. Since advertising is depreciated by growing number of Polish teenagers, buzz marketing appears to be a real alternative to traditional forms of marketing communication (Hughes, 2005; Leila, Abderrazak, 2013).

In addition, implementation of new technologies, such as social media and social network viral marketing may support the university's promotion program and attracts attention of prospect students. Word-of-mouth and recommendations supplied by social media are widespread used as a source of information about the educational institution (Sweeney et al., 2008). Therefore Polish universities should be encouraged to fully utilize buzz marketing with the support of social media outlets such as Facebook, Twitter, Linkedln or individual blogs. It must be stressed, that all social media tools, used to convey information about the university, students events, campus facilities etc. must be constantly updated and monitored to minimize negative comments. Yet, "word-ofmouth" and recommendations may be successfully used only if based on solid foundations: innovative and high quality educational offer, professional and kind university staff, encouraging post-graduation job perspectives, and well-designed websites.

\section{References}

Constatinides, E., Zinck Stagno, M. (2012). Higher Education Marketing: A Study on the Impact of Social Media on Study Selection and University Choice. International Journal of Technology and Education Marketing, 1 (2), 41-58.

Hall, H. (2007). Marketing w szkolnictwie. Warszawa: Wolters Kluwer Polska.

Hobsons (2013). Competing Globally: Understanding the decision-making processes of prospective international students. Retrieved from: https://www.hobsons.com/res/Whitepapers/24_Competing_Globally.pdf (20.09.2017).

Hughes, M. (2005). Marketing szeptany. Buzzmarketing. Z ust do ust. Jak zrobić szum medialny wokół siebie, firmy, produktu. Warszawa: MT Biznes.

Leila, C., Abderrazak, G. (2013). The Impact of the Effectiveness of a Buzz Marketing Campaign on the Image, Awareness and Purchasing Decision: The Moderating Role of Involvement. Journal of Marketing Research \& Case Studies, 1-8. 
Moogan, Y.J., Baron, S. (2003). An analysis of student characteristics within the student decision-making process. Journal of Further and Higher Education, 3 (27), 271-287.

Nowaczyk, G., Kolasiński, M. (2004). Marketing szkół wyższych. Poznań: Wydawnictwo Wyższej Szkoły Bankowej w Poznaniu.

Pabian, A. (2005). Marketing szkoły wyższej. Warszawa: Oficyna Wydawnicza ASPRA-JR.

Sankaran, V.S., Kannan, N. (2016). Effectiveness of Viral Marketing in Educational Institutions. International Journal of Applied Engineering Research, 2 (11), 1424-1431.

Smedescu, D.A., Ivanov, A.E., loanas, E., Fruth, A. (2016). Marketing Communications Mix in Higher Education Institutions. International Journal of Academic Research in Economics and Management Sciences, 4 (5), 291-298.

Sweeney, J.C., Soutar, G.N., Mazzarol, T. (2008). Factors influencing word of mouth effectiveness: receiver perspectives. European Journal of Marketing, 3/4 (42), 344-364.

Vrontis, D., Thrassou, A., Melanthiou, Y. (2007). A Contemporary Higher Education Student-Choice Model for Developed Countries. Journal of Business Research, 9 (60), 979-989.

Cite this article aS: Prymon-Ryś, E. (2018). The role of recommendations in promoting services of Polish universities. European Journal of Service Management, 2 (26), 209-216. DOI: 10.18276/ejsm.2018.26-26. 